\title{
Metals in organs of bottom sediments and aquatic plants of the Elk River and its tributaries
}

\author{
Elżbieta Skorbiłowicz, MirosławSkorbiłowicz, Emilia Zamojska, Paulina Wójtowicz \\ Bialystok University of Technology, Faculty of Building and Environmental Engineering; \\ ul.Wiejska 45E, 15-351 Bialystok, Poland; e-mail: e.skorbilowicz@pb.edu.pl
}

(C) 2018 Authors. This is an open access publication, which can be used, distributed and reproduced in any medium according to the Creative Commons CC-BY 4.0 License requiring that the original work has been properly cited.

Received: 12 December 2017; accepted: 12 June 2018

\begin{abstract}
The aim of the work was to analyze the content of $\mathrm{Ni}, \mathrm{Pb}$ and $\mathrm{Cd}$ in organs (root, stem, leaf) Typha latifolia L. and Nuphar lutea as well as bottom sediments of the Ełk River and selected tributaries. An attempt was also made to indicate the factors and processes governing the behavior of the investigated metals in the water environment of the examined rivers. The research object was the Ełk River with its three tributaries - the Gawlik River, the Binduga River and the Kuwasy Canal. Samples of bottom sediments, leaves, stems and roots of Typha latifolia L. and Nuphar lutea were collected in August of 2015. The content of metals was determined by flame atomic absorption spectrometry (F-AAS). The results of analyses of sediments and plant material indicate a lack of environmental pollution by nickel $\left(2.58-8.50 \mathrm{mg} \cdot \mathrm{kg}^{-1}\right)$ and lead $\left(3.82-15.99 \mathrm{mg} \cdot \mathrm{kg}^{-1}\right)$ of the Ełk River and its tributaries whereas the cadmium content ranged from $0.16-0.76 \mathrm{mg} \cdot \mathrm{kg}^{-1}$. Nuphar lutea and Typha latifolia $\mathrm{L}$. showed a varied capacity to accumulate nickel $\left(1.20-10.51 \mathrm{mg} \cdot \mathrm{kg}^{-1}\right)$ and lead $\left(0.04-14.16 \mathrm{mg} \cdot \mathrm{kg}^{-1}\right)$, occurring primarily in the roots. The smallest concentration of nickel and lead was recorded in the stems. The highest concentration of cadmium $\left(2.56 \mathrm{mg} \cdot \mathrm{kg}^{-1}\right)$ was noted in the roots and the lowest $(0.01 \mathrm{mg} \cdot \mathrm{kg})$ in the leaves. Factor analysis pointed to the processes of mobilizing elements from bottom sediments as a result of $\mathrm{pH}$ drop and their uptake by macrophyte roots and sorption processes of metal ions by macrophytes from river waters and their intensive accumulation in bottom sediments.
\end{abstract}

Keywords: river, metals, bottom sediments, aquatic plants

\section{INTRODUCTION}

Metal pollution of aquatic ecosystems has become an important global problem requiring urgent intervention due to the toxicity and non-biodegradability of these elements in the environment (Hanif et al. 2016, Xiaolei et al. 2016). Intensive industrial development and uncontrolled urbanization contribute to the excessive pollution of surface waters with metals, where they are bioaccumulated and even biomagnified in the trophic chain, which can have a negative impact on the environment and human health (Sojka et al. 2013, Morales-García et al. 2017). Metals in surface waters come mainly from anthropogenic sources, and to a much lesser extent from geological processes (Swennen \& Van der Sluys 2002, Demirak et al. 2006, Skorbiłowicz et al. 2014). The contribution of natural environmental pollution with heavy metals can be determined on the basis of tests of actual conditions and changes occurring in elements of aquatic ecosystems, such as bottom sediments and macrophytes (Baldantoni et. al. 2004, Bielski 2012, Hejabi \& Basavarajappa 2013, Harguinteguy et al. 2014). River sediments and aquatic plants are an integral part of surface waters, mainly due to 
the active participation in the circulation of elements (Dąbrowska \& Lejcuś 2012). There is a high relationship between the content of metals in river sediments and macrophytes vs. their concentration in water (Deng et al. 2004). This is the reason why they are a good indicator of the environment state and changes occurring in it (Klavins et al. 2000, Zurayk et al. 2001, Dong et al. 2004, Mazej \& Germ 2009, Królak et al. 2011). Analysis of bottom sediment composition is also necessary to recognize the sources and routes of trace metal migration in aquatic ecosystems (Głosińska \& Siepak 2007, Choiński et al. 2010, Ibragimow et al. 2010). Macrophytes, due to their constant contact with water and an extensive micronutrient accumulation system, have been used for many years as a biological indicator material (Rabajczyk \& Jóźwiak 2008, Skorbiłowicz et al. 2016), constituting an additional element in the assessment of metal concentrations in river and lake waters (Ali \& Jain 2001, Fediuc \& Erdei 2002, Mazej \& Germ 2009). Aquatic plants are used in the biomonitoring of the environment due to their ability to accumulate large amounts of metals (Gundersen \& Steinnes 2001, Fritioff \& Greger 2006, Bonanno 2010).

The aim of the work was to analyze the content of $\mathrm{Ni}, \mathrm{Pb}$ and $\mathrm{Cd}$ in organs (root, stem, leaf) of Typha latifolia L. and Nuphar lutea and bottom sediments of the Ełk river and its selected tributaries. An attempt was also made to indicate factors and processes governing the behavior of the investigated metals in the aquatic environment of the rivers examined.

\section{SITE DESCRIPTION AND METHODS}

The research object was the Ełk River with its three tributaries - Gawlik River, Binduga River and the Kuwasy Canal. The Ełk River is a rightbank tributary of the Biebrza River, about $113 \mathrm{~km}$ long. The catchment area covers $1525 \mathrm{~km}^{2}$. The river head is located in Szeska Góra near Gołdap, in the Warmian-Masurian Province. The course of the Ełk River ends in Osowiec, where it flows into the Biebrza River. The Ełk River catchment was formed by the Baltic glaciation and it is mainly made of boulder clays, sands and gravels. In the catchment, brown, leached and lessive brown soils occur showing low permeability. The majority of the area is arable land, grasslands and forests covering a vast area of the catchment. The industry situated within the Ełk River catchment is not a threat to the environment. Plants located close to the rivers and its tributaries deal mainly with food production, milk processing and to a small extent with industry (production of particle boards, paper packaging, doors, windows and heating devices). The largest sewage treatment plant in the Ełk River catchment area is located in Nowa Wieś Ełcka, to where wastewater from the city of Ełk is supplied. There are also smaller wastewater treatment plants located in Prostki and Grajewo. There are landfills located in the catchment area near Siedliska, Grajewo and Koszarówka.

In all, 10 sampling points for bottom sediments and macrophytes (Typha latifolia L., Nupharlutea) were determined on the Ełk River, whereas on the tributaries (Gawlik, Bindugi and Kuwasy Canal) one point was located in the lower courses of the rivers (Fig. 1). Selection of measuring points was dependent on the spatial distribution of pollution sources in the Ełk River catchment area. Samples of bottom sediments, leaves, stems and roots of the broadleaf club (Typha latifolia L.) and water lily (Nuphar lutea) were collected in August during the intensive growth of plants in 2015.

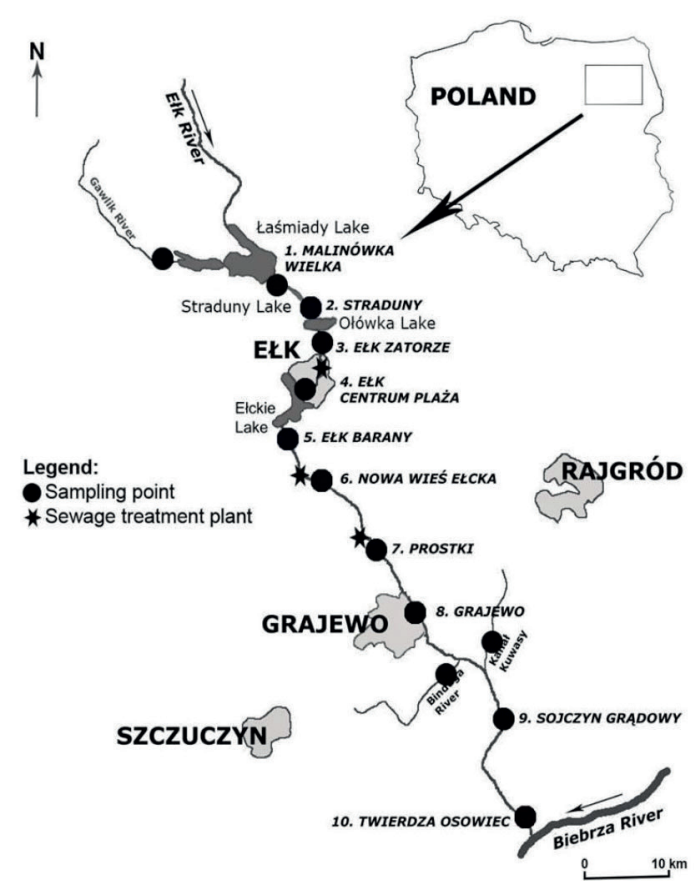

Fig. 1. Location of measurement and control points on Ełk river and its tributaries 
Table 1

The $\mathrm{pH}$ and range concentrations of trace metal contents in the bottom sediments of the Etk River and its tributaries

\begin{tabular}{|c|c|c|c|c|c|c|}
\hline \multirow[t]{2}{*}{ River } & \multirow{2}{*}{$\begin{array}{c}\text { Basic } \\
\text { statistics }\end{array}$} & $\mathrm{pH}$ & $\begin{array}{l}\text { Organic sub- } \\
\text { stance content }\end{array}$ & $\mathrm{Ni}$ & $\mathrm{Pb}$ & Cd \\
\hline & & {$[-]$} & {$[\%]$} & \multicolumn{3}{|c|}{$\left[\mathrm{mg} \cdot \mathrm{kg}^{-1}\right]$} \\
\hline \multirow{2}{*}{ Ełk River } & $\min -\max$ & $5.10-6.50$ & $2.90-4.60$ & $2.58-8.50$ & $3.82-15.99$ & $0.21-0.75$ \\
\hline & mean & - & 3.86 & 5.48 & 7.57 & 0.36 \\
\hline \multirow{2}{*}{ Ełk River tributary } & $\min -\max$ & $6.00-6.20$ & $4.10-4.60$ & $3.85-4.31$ & $4.86-5.19$ & $0.16-0.56$ \\
\hline & mean & - & 4.40 & 4.12 & 4.98 & 0.41 \\
\hline \multirow{2}{*}{\multicolumn{2}{|c|}{ Geochemical background }} & \multicolumn{2}{|c|}{ acc. to Turekian \& Wedepohl (1961) } & 68.0 & 20.0 & 0.35 \\
\hline & & \multicolumn{2}{|c|}{ acc. to Bojakowska (2001) } & 5.0 & 15.0 & $<0.5$ \\
\hline
\end{tabular}

Bottom sediment was collected in the peripheral zone from the top layer, where deposition of suspended material and accumulation of metals occurs (Bojakowska 2001). Ten individual samples of bottom sediments were collected at a depth of 5-10 $\mathrm{cm}$ from the water surface at each designated measurement point. After mixing the test material, a representative sample of about $1000 \mathrm{~g}$ was obtained. The samples were dried to an "air-dry" state and stored until the assays (Lis \& Pasieczna 1995). Prior to chemical analyses, the bottom sediment samples were dried at a temperature of $40^{\circ} \mathrm{C}$ and disaggregated to pass a $0.2 \mathrm{~mm}$ sieve. Bottom sediments were mineralized with hydrochloric and nitric acid in a volume ratio of 3:1 in a closed CEM microwave system. All determinations were carried out in triplicate. After filtration, the samples were quantitatively transferred to $50 \mathrm{ml}$ graduated flasks. The content of metals was determined by flame atomic absorption spectrometry (F-AAS) using the AAS ICE 3500 Thermo Scientific spectrometer. Results of sediment analyses were verified using a certified reference material for sediments NCS DC 73317a. Calculated measurement error did not exceed $5 \%$ of the certified value. The reaction of bottom sediments was determined by means of the potentiometric method. Organic substance content was determined on the basis of the weight difference of samples before and after combustion at $450^{\circ} \mathrm{C}$. The $\mathrm{pH}$ of sediments in the water was measured potentiometrically. The obtained results of metal content $(\mathrm{Ni}, \mathrm{Pb}$ and Cd) were given in relation to air dry sediments and compared with literature data. To assess the degree of the metal contamination of sediments, the proposed classification of water sediments in Poland was used (Bojakowska 2001) and the contents of investigated metals were compared to the geochemical background proposed by Turekian and Wedepohl (1961). To assess the quality of bottom sediments of the Ełk River and its tributaries, the degree of sediment pollution was also determined, using the geochemical index $\left(\mathrm{I}_{\text {geo }}\right)$ and the contamination factor (CF).

Geochemical index $\left(\mathrm{I}_{\text {geo }}\right)$ is defined using the following formula (Müller 1979):

$$
\mathrm{I}_{\mathrm{geo}}=\log _{2}\left(\frac{\mathrm{C}_{\mathrm{m}}}{1.5 \mathrm{GM}}\right)
$$

where:

$\mathrm{C}_{\mathrm{m}}$ - content of analyzed metal $\left[\mathrm{mg} \cdot \mathrm{kg}^{-1}\right]$,

$\mathrm{GM}$ - geochemical background $\left[\mathrm{mg} \cdot \mathrm{kg}^{-1}\right.$.

The $\mathrm{I}_{\text {geo }}$ values are divided into seven classes, i.e. non-polluted sediment class $0\left(\mathrm{I}_{\text {geo }} \leq 0\right)$, poorly polluted sediment class $1\left(0<\mathrm{I}_{\text {geo }}<1\right)$, moderately contaminated sediment class $2\left(1<\mathrm{I}_{\text {geo }}<2\right)$, averagely contaminated sediment class $3\left(2<\mathrm{I}_{\text {geo }}<3\right)$, highly contaminated sediment class $4\left(3<\mathrm{I}_{\mathrm{geo}}<4\right)$, very heavily polluted class $5\left(4<\mathrm{I}_{\mathrm{geo}}<5\right)$, extremely contaminated sediment class $6\left(I_{\text {geo }} \geq 5\right)$.

Contamination factor was determined as a ratio of the total metal content to the geochemical background value (Häkanson 1980):

$$
\mathrm{CF}=\frac{\mathrm{C}_{\mathrm{m}}}{\mathrm{GM}}
$$

where:

$\mathrm{C}_{\mathrm{m}}$ - content of analyzed metal $\left[\mathrm{mg} \cdot \mathrm{kg}^{-1}\right]$,

GM - geochemical background $\left[\mathrm{mg}^{\mathrm{k}} \mathrm{kg}^{-1}\right]$. 
Bottom sediments were classified on the basis of the obtained values of contamination factor (CF), according to the following ranges: $\mathrm{CF}<1-$ class I (low contamination), $1 \leq \mathrm{CF} \leq 3$ - class II (medium contamination), $3<\mathrm{CF}<6$ - class III (significant contamination), $\mathrm{CF} \geq 6$ - class IV (very high contamination).

Two aquatic plants Nuphar lutea and Typha latifolia L. were selected for testing in the Ełk River and its tributaries. Nuphar lutea in Poland occurs mainly in lowlands, where it is a common plant. It grows in river waters at a depth of 50-200 cm, which are rich in organic substances, as well as in places where the bottom of the riverbed is sandysilty or muddy. Typha latifolia L. is widely spread in Poland. It grows on the banks of stagnant and slow flowing waters. It often creates extensive, usually almost single-species rushes. Plants of this species are used for phytoremediation. Macrophyte samples were made from combining ten single samples. The plants transported to the laboratory were washed with running water and distilled water, then dried at $80^{\circ} \mathrm{C}$ (Mazej \& Germ 2009). Dried roots, stems and leaves were homogenized and digested with hydrochloric and nitric acid in a 3:1 volume ratio in a closed CEM microwave system. The content of heavy metals was determined by the F-AAS method employing the AAS ICE 3500 Thermo Scientific spectrometer. The standard reference material (SRM) used for measuring trace element concentrations was the grass mixture ERM-CD281 and strawberry leaves - LGC7162. Calculated measurement error did not exceed 5\% of the certified value. The obtained results of determined metals content were given in relation to the dry mass of plants and compared with literature data also referring to dry matter of plants. The physiological levels of metal content for plants is given according to data provided by Kabata-Pendias \& Pendias (1999). In the analysis of plant results, the bioconcentration coefficient expressed by the ratio of the metal content in a plant root to the metal content in bottom sediment and the translocation coefficient, were calculated. The translocation coefficient was calculated as the quotient of the content of examined metal in roots and stems, as well as in root and leaf of tested macrophyte.

To analyze the obtained numerical data, statistical multivariate analysis (FA) and Ward cluster analysis (CA) were applied. Before calculations, the normality of the data distribution at $(p \leq 0.05)$ was checked. Normal distribution of the variables tested was not shown. Therefore, the transformation variables were changed, after which a normal distribution was obtained. After transformation, all of the analyzed metal contents had a normal distribution at the level of $p=0.05$. Before performing multidimensional analyses, basic relationships in the prepared data set were also checked using Spearman's rank order correlation (bottom sediments - Nuphar lutea and Typha latifolia L. separately). The prepared data set was analyzed using two multidimensional statistical methods, i.e.: CA and FA. Cluster analysis (CA) was performed using the Ward method to visualize the similarities and differences between studied parameters of bottom sediment samples and macrophytes (separately Nuphar lutea and Typha latifolia L.) (Shrestha \& Kazama 2007). The FA method was used to expose factors characterizing the variability of metal content in bottom sediments and macrophytes (separately Nuphar lutea and Typha latifolia L.).

\section{RESULTS AND DISCUSSION}

River sediments play an important role in the circulation of elements in aquatic ecosystems (Skorbiłowicz et al. 2016). The content of metals in bottom sediments is an indicator of their long-term accumulation in reservoirs and watercourse sediments (Baldantoni et al. 2005). One of the reasons for the differences in the amount of metals in bottom sediments is their grain size. Huang \& Lin (2003) state that metal pollution depends on the mineral composition and the size of the sediment particles. According to Zhao et al. (1999), the content of metals in the river strongly depends on the particle size distribution of the sediment. The analyzed bottom sediments had loose sand and light loamy sand properties. Bottom sediments of the Ełk River and its tributaries were characterized by a fairly diverse reaction, acidic and slightly acidic, which ranged from 5.1 to $6.5 \mathrm{pH}$ (Tab. 1). The average organic matter content in the Ełk River was $3.86 \%$. The greater regularity of organic matter content in the upper and middle courses of the river was probably related to the flow velocity, volume 
of indigenous primary production, its decomposition, and re-suspension processes. By comparison, the content of organic matter in the tributaries was as follows: Gawlik $-4.10 \%$, Binduga $-4.50 \%$, Kuwasy Canal $-4.60 \%$. A significant percentage of these river basins are taken up by forests and peatbogs which are the source of organic matter deposited in the bottom sediments of the rivers.

Figures 2-4 show the contents of investigated metals in the Ełk River and its tributaries. The content of nickel and lead in bottom sediments was small and remained within the geochemical background (Turekian \& Wedepohl 1961) and the first geochemical class (Bojakowowska 2001). The largest amounts of lead were recorded in point 8 - Grajewo $\left(15.99 \mathrm{mg} \cdot \mathrm{kg}^{-1}\right)$, which is located near a very busy road. Therefore, larger amounts of lead from transport are accumulated in these bottom sediments. In the case of cadmium, its content exceeded the geochemical background of the Ełk River at points 1 - Malinówka Wielka (0.75 mg.kg $\left.{ }^{-1}\right), 2$ - Straduny $\left(0.51 \mathrm{mg} \cdot \mathrm{kg}^{-1}\right)$, 5 - Ełk Barany $\left(0,58 \mathrm{mg} \cdot \mathrm{kg}^{-1}\right)$ and in the Binduga tributary $\left(0.56 \mathrm{mg} \cdot \mathrm{kg}^{-1}\right)$. A significant level of cadmium in sediments indicates the accumulation

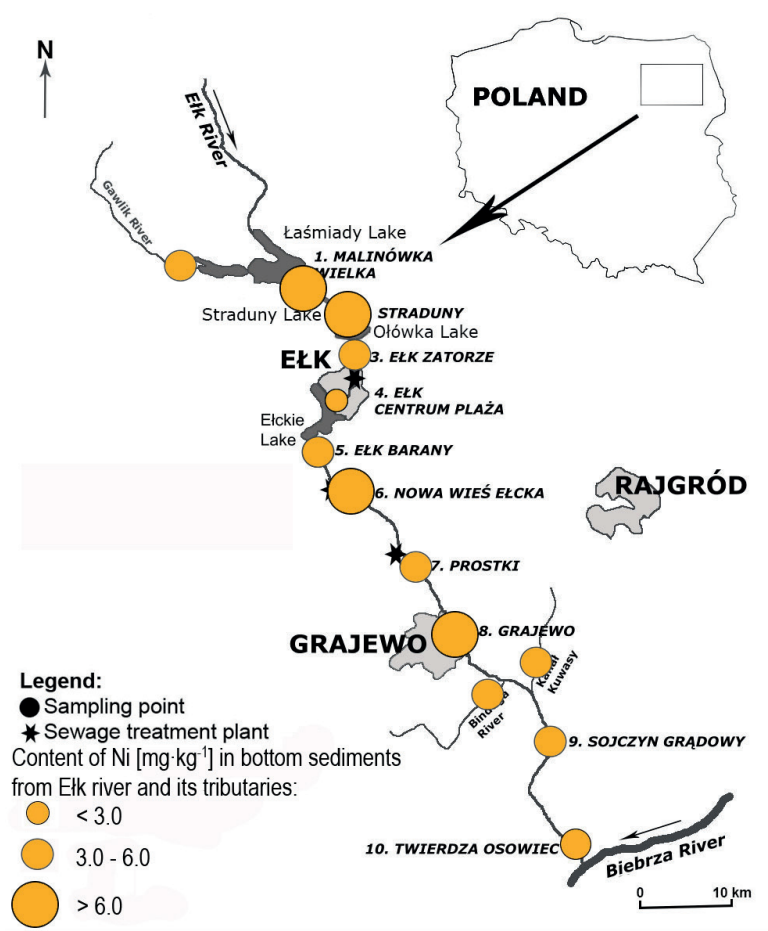

Fig. 2. Content of $\mathrm{Ni}$ in bottom sediments from Ełk river and its tributaries of contaminants from surface runoff and mineral fertilization from nearby agricultural land. The research also showed that most of nickel and cadmium in the bottom sediments was at point 1 Malinówka Wielka, which indicates the influence of anthropogenic factors such as intensively developing tourism, agritourism and the impact of Lake Łaśmiady.

The mean contents of investigated metals in the bottom sediment were in the following order: $\mathrm{Pb}>\mathrm{Ni}>\mathrm{Cd}$. The sediments examined, in terms of nickel and lead content according to the Häkansons classification, are uncontaminated and have low coefficients, which indicates that they are not contaminated with these metals. In the case of cadmium contamination - it was found in bottom sediments samples from measuring points $(1,2,5,12)$, wich may be caused by agricultural activity (Fig. 3).

As confirmed by values of the geoaccumulation index $\left(\mathrm{I}_{\text {geo }}\right)$, the sediments of the Ełk River and its tributaries were uncontaminated (class 0 ) by $\mathrm{Pb}$ and $\mathrm{Ni}$. In the case of cadmium, the sediments were uncontaminated (class 0 ) in nine samples, slightly contaminated (class I) in four sediment samples (Tab. 2).



Fig. 3. Content of $C d$ in bottom sediments from Ełk river and its tributaries 
Table 2

Values of geochemical index $\left(I_{g e o}\right)$ and contamination factor $(C F)$ determined for the bottom sediments of the Ełk River and its tributaries

\begin{tabular}{|l|l|c|c|c|c|c|c|}
\hline \multirow{2}{*}{ River } & \multirow{2}{*}{$\begin{array}{c}\text { Basic } \\
\text { statistics }\end{array}$} & \multicolumn{2}{|c|}{ Ni } & \multicolumn{2}{c|}{ Pb } & \multicolumn{2}{c|}{ Cd } \\
\cline { 3 - 8 } & & $\mathbf{I}_{\text {geo }}$ & CF & $\mathbf{I}_{\text {geo }}$ & CF & $\mathbf{I}_{\text {geo }}$ & CF \\
\hline $\begin{array}{l}\text { Ełk River and } \\
\text { its tributaries }\end{array}$ & min-max & $(-5.31)-(-3.58)$ & $0.04-0.13$ & $(-2.97)-(-0.91)$ & $0.19-0.80$ & $(-1.74)-0.52$ & $0.45-2.14$ \\
\cline { 2 - 8 } & mean & - & 0.076 & - & 0.349 & - & 1.064 \\
\hline
\end{tabular}

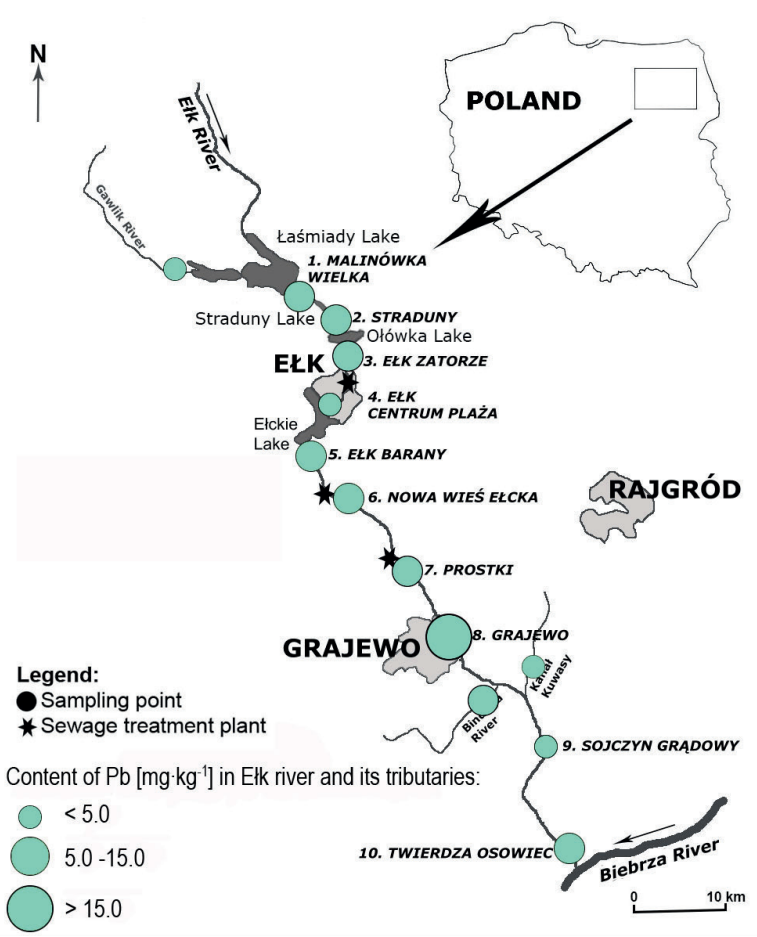

Fig. 4. Content of $\mathrm{Pb}$ in Ełk river and its tributaries
The obtained metals content in the bottom sediments collected in the Ełk River and its tributaries was compared with that in sediments of the other rivers around the world, as shown in Table 3. Olivares-Rieumont et al. (2005) found high content of $\mathrm{Pb}\left(189.0 \mathrm{mg} \cdot \mathrm{kg}^{-1}\right)$ and $\mathrm{Cd}\left(4.3 \mathrm{mg} \cdot \mathrm{kg}^{-1}\right)$ in the bottom sediment of the Almendares River (Cuba). Singh et al. (2005) also noted high $\mathrm{Pb}\left(92.2 \mathrm{mg} \cdot \mathrm{kg}^{-1}\right)$ and $\mathrm{Cd}\left(7.9 \mathrm{mg} \cdot \mathrm{kg}^{-1}\right)$ contents in the bottom sediments of the Gomti River (India). Bonanno et al. (2010) reported much higher Ni content $\left(29.14 \mathrm{~kg} \cdot \mathrm{kg}^{-1}\right)$ in the bottom sediments of the Salso River (Italy) than was found in the bottom sediments of the Ełk River and its tributaries. Studies on the Gowienioca River showed higher contents of $\mathrm{Ni}$ and $\mathrm{Pb}$, but lower contents of Cd (Szydłowski \& Podlasińska 2017).

A comparison of metal content in the bottom sediments of the Ełk River and its tributaries to the content of metals in river sediments throughout the world shows that the contents of analyzed elements in the sediments of the study area are much lower compared to other aquatic ecosystems in the world.

Table 3

Comparison of metal contents in the bottom sediments of the Etk River and its tributaries with the selected rivers across the world

\begin{tabular}{|c|c|c|c|c|}
\hline \multirow{2}{*}{ River } & $\mathrm{Ni}$ & $\mathbf{P b}$ & Cd & \multirow{2}{*}{ Author } \\
\hline & \multicolumn{3}{|c|}{$\left[\mathrm{mg} \cdot \mathrm{kg}^{-1}\right]$} & \\
\hline \multicolumn{5}{|c|}{ BOTTOM SEDIMENTS } \\
\hline Ełk River and its tributaries & 5.17 & 6.97 & 0.37 & own study \\
\hline Chenab R., Pakistan & - & 18.1 & 1.67 & Hanif et al. (2016) \\
\hline Gomti R., India & - & 92.2 & 7.9 & Singh et al. (2005) \\
\hline Almendares R., Cuba & - & 189.0 & 4.3 & Olivares-Rieumont et al. (2005) \\
\hline Salso R., Italy & 29.14 & 2.67 & 0.66 & Bonanno et al. (2010) \\
\hline Gowienica, Poland & 18.34 & 14.84 & 0.10 & Szydłowski et al. (2016) \\
\hline \multicolumn{5}{|c|}{ MACROPHYTES } \\
\hline Ełk River and its tributaries & 3.09 & 4.75 & 0.47 & this study \\
\hline Brisbane, Australia & - & 107.0 & 2.53 & Cardwell et al. (2002) \\
\hline Morello, Italy & 10.1 & 2.9 & 0.21 & \multirow{3}{*}{ Bonanno \& Vymazal (2017) } \\
\hline Acquicella, Italy & 20.5 & 53.2 & 0.51 & \\
\hline Capodarso, Italy & 6.92 & 6.92 & 0.32 & \\
\hline Fenghuangshan, China & - & 202.67 & 0.82 & Shen et al. (2017) \\
\hline Pilica, Poland & - & 21.00 & - & Samecka-Cymerman \& Kempas (2004) \\
\hline
\end{tabular}


Figures 5-7 and Table 4 present contents of $\mathrm{Ni}$, $\mathrm{Pb}$ and $\mathrm{Cd}$ in the roots, stems and leaves of studied macrophytes collected along the Ełk River and its three tributaries. By analyzing the content of individual elements in aquatic plants, it is possible to determine the current state of the aquatic environment and changes occurring in it (Klavins et al. 2000, Dong et al. 2004, Hejabi \& Basavarajappa 2013). Nuphar lutea and Typha latifolia L. were selected for analysis as test plants due to their presence at all measuring points (common across the country), a high number of occurrences and ease of taking the plant samples from rivers, collecting large amounts of metals, are advantages that facilitate interpretation of results.

According to Melville \& Pulkownik (2007), organisms assigned to good bioindicators are those that were settled, easy to interpret and cosmopolitan. In contrast, Rainbow \& Phillips (1993) argue that bioindicators should also be sensitive to pollution and tolerate large concentrations in the environment. The studied macrophytes Nuphar lutea and Typha latifolia L. showed different abilities to accumulate nickel and lead, occurring primarily in the roots and leaves. The smallest contribution of nickel and lead was recorded in stems. In

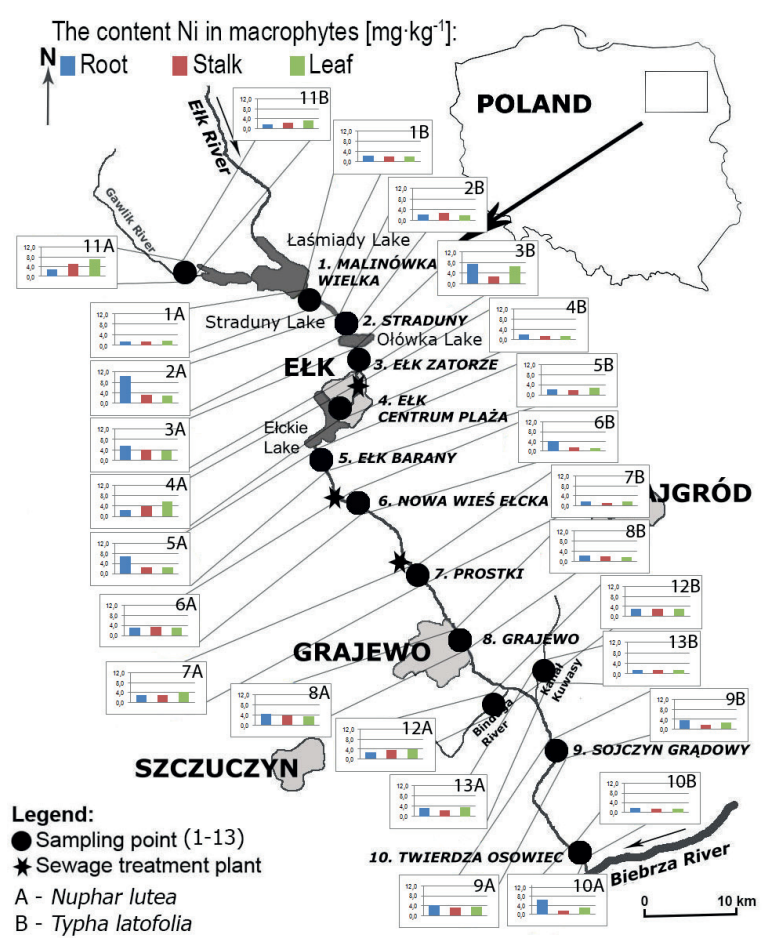

Fig. 5. Content of Ni in particular organs of test macrophytes from Etk river and its tributaries the case of cadmium in the analyzed plants, the highest concentrations of this element were in roots and least in leaves.

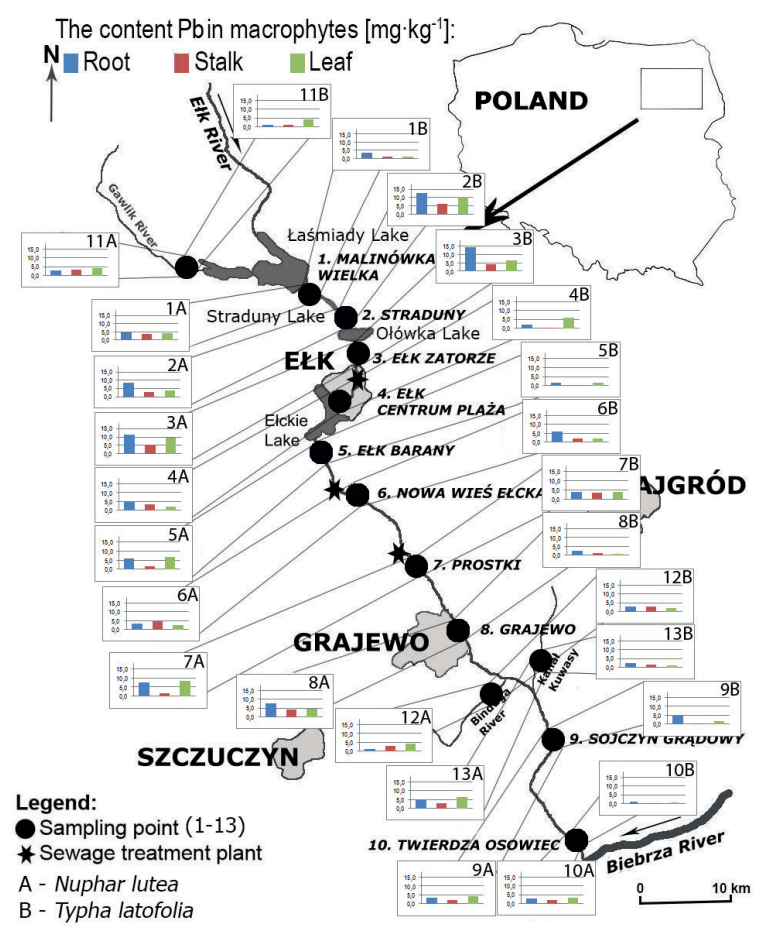

Fig. 6. Content of $\mathrm{Pb}$ in particular organs of test macrophytes from Ełk river and its tributaries

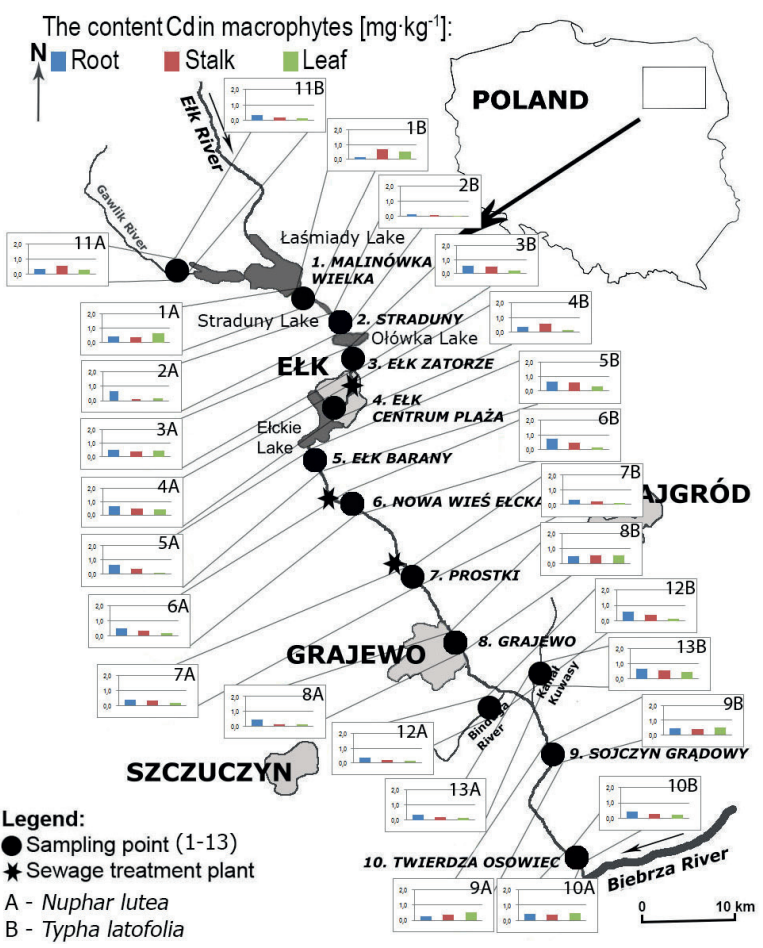

Fig. 7. Content of $C d$ in particular organs of test macrophytes from Ełk river and its tributaries 
Table 4

Ranges of metal content in the water plants of the Elk River and its tributaries

\begin{tabular}{|c|c|c|c|c|c|c|c|c|c|c|c|}
\hline \multirow{3}{*}{ River } & \multirow{3}{*}{$\begin{array}{c}\text { Plant } \\
\text { species }\end{array}$} & \multirow{3}{*}{$\begin{array}{c}\text { Basic } \\
\text { statis- } \\
\text { tics }\end{array}$} & \multicolumn{3}{|c|}{$\mathrm{Ni}$} & \multicolumn{3}{|c|}{$\mathrm{Pb}$} & \multicolumn{3}{|c|}{$\mathrm{Cd}$} \\
\hline & & & \multicolumn{3}{|c|}{$\left[\mathrm{mg} \cdot \mathrm{kg}^{-1}\right]$} & \multicolumn{3}{|c|}{$\left[\mathrm{mg} \cdot \mathrm{kg}^{-1}\right]$} & \multicolumn{3}{|c|}{$\left[\mathrm{mg} \cdot \mathrm{kg}^{-1}\right]$} \\
\hline & & & root & stem & leaf & root & stem & leaf & root & stem & leaf \\
\hline \multirow{4}{*}{$\begin{array}{l}\text { Ełk } \\
\text { River }\end{array}$} & \multirow{2}{*}{$\begin{array}{l}\text { Nuphar } \\
\text { lutea }\end{array}$} & $\min -\max$ & $\begin{array}{l}1.43- \\
10.51\end{array}$ & $1.31-4.13$ & $1.79-5.68$ & $2.91-11.25$ & $1.48-5.43$ & $1.92-9.75$ & $0.29-0.69$ & $0.10-0.50$ & $0.04-0.67$ \\
\hline & & mean & 4.80 & 3.05 & 3.42 & 6.02 & 3.16 & 5.01 & 0.50 & 0.32 & 0.32 \\
\hline & \multirow{2}{*}{$\begin{array}{l}\text { Typha } \\
\text { latifolia } \\
\text { L. }\end{array}$} & $\min -\max$ & $1.70-7.49$ & $1.21-2.76$ & $1.20-6.56$ & $1.10-14.16$ & $0.22-6.61$ & $\begin{array}{l}0.62- \\
10.56\end{array}$ & $0.14-0.77$ & $0.11-0.70$ & $0.01-0.55$ \\
\hline & & mean & 3.01 & 1.90 & 2.40 & 5.18 & 2.03 & 3.41 & 0.44 & 0.44 & 0.28 \\
\hline \multirow{4}{*}{$\begin{array}{l}\text { Tribu- } \\
\text { taries of } \\
\text { the Ełk } \\
\text { River }\end{array}$} & \multirow{2}{*}{$\begin{array}{l}\text { Nuphar } \\
\text { lutea }\end{array}$} & $\min -\max$ & $2.71-3.29$ & $2.40-5.14$ & $3.74-6.91$ & $1.35-4.62$ & $\begin{array}{l}2.97- \\
10.35 \\
\end{array}$ & $4.12-7.32$ & $0.02-1.15$ & $0.13-2.56$ & $0.08-2.28$ \\
\hline & & mean & 2.95 & 3.70 & 4.83 & 2.93 & 5.46 & 5.98 & 0.50 & 0.97 & 0.84 \\
\hline & \multirow{2}{*}{$\begin{array}{l}\text { Typha } \\
\text { latifolia } \\
\text { L. }\end{array}$} & $\min -\max$ & $1.57-3.07$ & $1.50-3.01$ & $2.59-3.39$ & $1.31-3.44$ & $0.73-2.70$ & $0.04-4.24$ & $0.32-0.87$ & $0.55-1.42$ & $0.13-1.29$ \\
\hline & & mean & 2.10 & 2.29 & 3.01 & 2.55 & 1.52 & 2.08 & 0.61 & 0.88 & 0.63 \\
\hline \multicolumn{3}{|c|}{$\begin{array}{l}\text { Natural content by Kabata- } \\
\text { Pendias (1999) }\end{array}$} & \multicolumn{3}{|c|}{$<10.0$} & \multicolumn{3}{|c|}{30.0} & \multicolumn{3}{|c|}{0.15} \\
\hline
\end{tabular}

Bragato et al. (2006), Bonanno \& Giudice (2010) in their research showed that metals are accumulated mainly in roots as documented by the results of our research. Macrophytes with a well-developed root system mainly intake metals through the roots (Stoltz \& Greger 2002). Laboratory experiments also confirmed higher accumulation of metals in roots than in stems and leaves (Weis et al. 2004). The present studies also showed that the degree of accumulation depended on the plant species. Higher nickel contents were observed in Nuphar lutea (mean of $3.77 \mathrm{mg} \cdot \mathrm{kg}^{-1}$ ) than in Typha latifolia L. $\left(2.42 \mathrm{mg} \cdot \mathrm{kg}^{-1}\right)$. The same relationships was revealed by lead: Nuphar lutea (mean of $4.49 \mathrm{mg} \cdot \mathrm{kg}^{-1}$ ) compared to Typha latifolia L. $\left(3.21 \mathrm{mg} \cdot \mathrm{kg}^{-1}\right)$. The average cadmium content in both studied plants was similar (0.35 mg.kg ${ }^{-1}$ - Nuphar lutea, $0.39 \mathrm{mg} \cdot \mathrm{kg}^{-1}-\mathrm{Ty}$ pha latifolia L.). Differences in the content of metals in the roots, shoots, leaves or reproductive organs depend on the mobility (movement from the roots to the shoot) of toxic ions (Wojtkowska 2014). Metals in the studied aquatic plants in the Ełk River and its tributaries were accumulated in the following order, roots and leaves: $\mathrm{Pb}>\mathrm{Ni}>\mathrm{Cd}$ and stem: $\mathrm{Ni}>\mathrm{Pb}>\mathrm{Cd}$. The research proved that the amount of analyzed metals depended on the sampling site. The highest content of these metals was recorded at point 3 - Ełk Zatorze. In the vicinity of this measurement point, there is a window and door production plant, a precast concrete element plant, a metal products plant and meat plants. The obtained test results showed a higher content of nickel, lead in the bottom sediments than in the studied plants; similar average values were obtained for cadmium in the plants and sediments. In order to compare the content of metals in the bottom sediments and plant roots, bioconcentration factors (roots/ sediment) were used (Tab. 5). The higher mean BCF values found in Nuphar lutea were as follows: $\mathrm{Ni}$ (0.92), $\mathrm{Pb}$ (0.94), Cd (1.65). Slightly lower mean $\mathrm{BCF}$ values were obtained for $\mathrm{Ni}(0.60), \mathrm{Pb}(0.82)$, Cd (1.56) for Typha latifolia L. According to Szarek-Gwiazda (2013), the presence of metals in sediments determines their availability for some macrophyte species.

Values of translocation coefficients illustrate the mobility of the analyzed metals in the stemroot and leaf-root pathways. The TF $>1$ values indicate a high degree of translocation. In the case of $\mathrm{Ni}$ and $\mathrm{Pb}$ in the root-leaf system in both plants, the TF value occurred above 1 in $38 \%$, for Cd between the root-stem and root-leaf, it was about $20 \%$. Bound metals in the roots prevent them from entering the shoots ("detoxify" the aboveground part) (Harada et al. 2001).

Lead, cadmium and nickel contents in Nuphar lutea and Typha latifolia L. were typical for aquatic environments with low metal contamination and lower than those reported in contaminated ecosystems (Cardwell et al. 2002, Shen et al. 2017) (Tab. 3). An enrichment occurred only in the case of cadmium Kabata-Pendias (1999). 
Table 5

Ranges of the bio-concentration factor (BCF) and translocation factor (TF) determined for aquatic plants of the Ełk River and its tributaries

\begin{tabular}{|c|c|c|c|c|c|c|c|c|c|c|c|}
\hline \multirow[b]{2}{*}{ River } & \multirow{2}{*}{$\begin{array}{c}\text { Plant } \\
\text { species }\end{array}$} & \multirow{2}{*}{$\begin{array}{c}\text { Basic } \\
\text { statis- } \\
\text { tics }\end{array}$} & \multicolumn{3}{|c|}{$\mathrm{Ni}$} & \multicolumn{3}{|c|}{$\mathbf{P b}$} & \multicolumn{3}{|c|}{ Cd } \\
\hline & & & $\begin{array}{l}\text { bottom/ } \\
\text { root }\end{array}$ & $\begin{array}{c}\text { stem/ } \\
\text { root }\end{array}$ & $\begin{array}{l}\text { leaf/ } \\
\text { root }\end{array}$ & $\begin{array}{c}\text { bottom/ } \\
\text { root }\end{array}$ & $\begin{array}{c}\text { stem/ } \\
\text { root }\end{array}$ & $\begin{array}{l}\text { leaf/ } \\
\text { root }\end{array}$ & $\begin{array}{c}\text { bottom/ } \\
\text { root }\end{array}$ & $\begin{array}{c}\text { stem/ } \\
\text { root }\end{array}$ & $\begin{array}{l}\text { leaf/ } \\
\text { root }\end{array}$ \\
\hline \multirow{4}{*}{$\begin{array}{l}\text { Ełk } \\
\text { River }\end{array}$} & \multirow{2}{*}{$\begin{array}{l}\text { Nuphar } \\
\text { lutea }\end{array}$} & $\begin{array}{l}\min - \\
\max \end{array}$ & $0.17-1.58$ & $0.25-1.76$ & $0.28-2.46$ & $0.33-2.10$ & $0.20-1.42$ & $0.37-1.29$ & $0.59-3.25$ & $0.19-1.21$ & $0.07-1.83$ \\
\hline & & mean & 0.92 & 0.81 & 0.96 & 0.94 & 0.60 & 0.88 & 1.65 & 0.69 & 0.73 \\
\hline & \multirow{2}{*}{$\begin{array}{l}\text { Typha } \\
\text { latifolia } \\
\text { L. }\end{array}$} & $\begin{array}{l}\min - \\
\max \end{array}$ & $0.28-1.66$ & $0.36-1.17$ & $0.29-1.23$ & $0.12-2.64$ & $0.09-0.92$ & $0.28-3.18$ & $0.19-3.08$ & $0.61-5.00$ & $0.06-3.64$ \\
\hline & & mean & 0.60 & 0.73 & 0.83 & 0.82 & 0.36 & 0.84 & 1.56 & 1.29 & 0.82 \\
\hline \multirow{4}{*}{$\begin{array}{l}\text { Tribu- } \\
\text { taries of } \\
\text { the Ełk } \\
\text { River }\end{array}$} & \multirow{2}{*}{$\begin{array}{l}\text { Nuphar } \\
\text { lutea }\end{array}$} & $\begin{array}{l}\min - \\
\max \end{array}$ & $0.64-0.85$ & $0.73-1.80$ & $1.14-2.42$ & $0.26-0.95$ & $0.66-2.20$ & $1.41-3.05$ & $0.32-2.10$ & $0.60-1.70$ & $0.44-0.85$ \\
\hline & & mean & 0.72 & 1.28 & 1.66 & 0.60 & 1.35 & 2.00 & 1.03 & 1.01 & 0.58 \\
\hline & \multirow{2}{*}{$\begin{array}{l}\text { Typha } \\
\text { latifolia } \\
\text { L. }\end{array}$} & $\begin{array}{l}\min - \\
\max \end{array}$ & $0.38-0.73$ & $0.96-1.42$ & $1.00-2.05$ & $0.27-0.56$ & $0.71-0.93$ & $0.43-3.24$ & $1.13-2.00$ & $0.53-0.82$ & $0.24-0.67$ \\
\hline & & mean & 0.51 & 1.12 & 1.35 & 0.44 & 0.84 & 1.45 & 1.46 & 0.67 & 0.44 \\
\hline
\end{tabular}

The analysis of Spearman's rank order correlation showed the effect of organic matter on the $\mathrm{pH}$ value (0.55), which may be the result of a weak organic acids presence in it. There were also visible, but weaker, dependences of $\mathrm{Ni}$ content in the roots of Nuphar lutea on its content in sediments (0.32), $\mathrm{Pb}(0.22)$ and $\mathrm{Cd}(0.11)$.

Statistical analysis of CA concentrations of metal content in bottom sediments and
Nuphar lutea showed two groups characterized by different metal content (Fig. 8). The first group showed $\mathrm{Ni}$ and $\mathrm{Pb}$ in the sediments and parts of plants, as well as the reaction and the organic substance. The second group, however, indicated $\mathrm{Cd}$ in all the samples tested (bottom sediments, roots, stems and leaves) which may indicate the impact of agricultural activity.

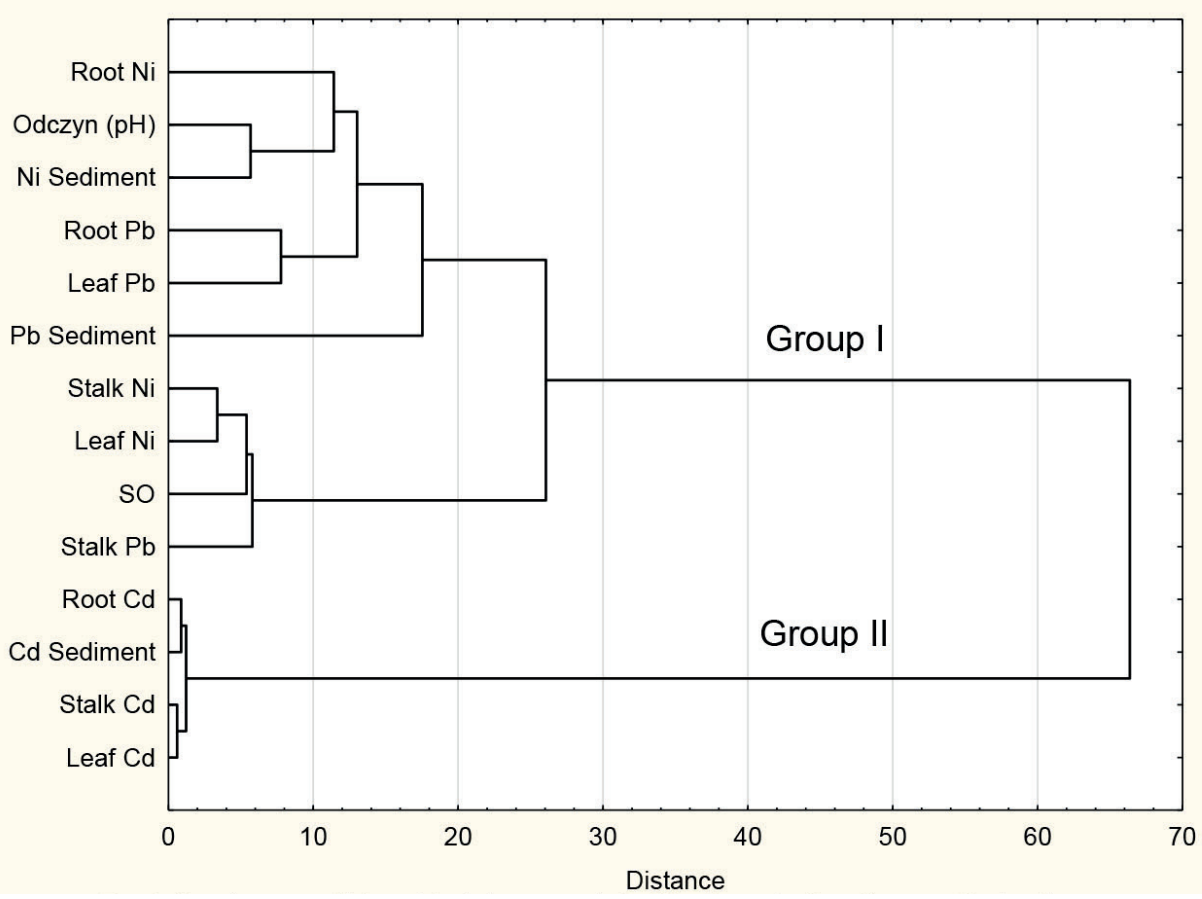

Fig. 8. Dendrogram of hierarchical cluster analysis (Ward's method) sediment - Nuphar lutea 
The results of the performed analysis are probably overlapped, as previously demonstrated, by geochemical background concentrations in the bottom sediments and high values of bioaccumulation coefficients in the case of $\mathrm{Cd}$.

The FA factor analysis did not show a full agreement with the CA cluster analysis. The cumulative variance for the factors $\mathrm{F} 1$ and $\mathrm{F} 2$ is $26 \%$ and $23 \%$, respectively (Tab. 6). Only the Cd content in sediments refers to the previous CA results. The first factor is also related to the Ni content in sediments, as well as to the decrease of its contents in stem and leaf, the second factor may be related to the gradual the $\mathrm{pH}$ drop of sediment, the result of which is the activation of $\mathrm{Cd}$ and $\mathrm{Pb}$ and its intense biosorption by macrophyte roots.

\section{Table 6}

The factor loadings after the varimax rotation of the sediments and macrophytes data. Values indicate statistically significant scores $\geq 0.70$

\begin{tabular}{|l|c|c|}
\hline \multicolumn{1}{|c|}{ Parameters } & Factor $\mathbf{1}$ & Factor $\mathbf{2}$ \\
\hline Root $\mathrm{Ni}$ & 0.39 & 0.46 \\
\hline $\mathrm{Stem} \mathrm{Ni}$ & $\mathbf{- 0 . 7 7}$ & 0.29 \\
\hline Leaf $\mathrm{Ni}$ & $\mathbf{- 0 . 9 1}$ & -0.07 \\
\hline Root $\mathrm{Pb}$ & 0.15 & $\mathbf{0 . 8 4}$ \\
\hline Stem $\mathrm{Pb}$ & -0.16 & 0.43 \\
\hline Leaf $\mathrm{Pb}$ & 0.04 & 0.27 \\
\hline Root $\mathrm{Cd}$ & 0.11 & $\mathbf{0 . 8 1}$ \\
\hline Stem $\mathrm{Cd}$ & -0.59 & -0.05 \\
\hline Leaf Cd & -0.01 & -0.19 \\
\hline Acidity $(\mathrm{pH})$ & 0.39 & $-\mathbf{0 , 7 0}$ \\
\hline SO & 0.08 & $-\mathbf{0 , 8 8}$ \\
\hline Ni sediment & $\mathbf{0 . 7 9}$ & 0.06 \\
\hline Pb sediment & 0.63 & 0.19 \\
\hline Cd sediment & $\mathbf{0 . 7 4}$ & -0.15 \\
\hline \% Variance & 26 & 23 \\
\hline
\end{tabular}

\section{Bottom sediments - Typha latifolia L.}

The relationships between bottom sediments Typha latifolia L. roots according to Spearman's correlation turned out to be similar to Nuphar lutea ( $\mathrm{Ni} \mathrm{0.28,} \mathrm{Pb} 0.09, \mathrm{Cd} 0.22)$. The dependences of metal content in individual Typha latifolia $\mathrm{L}$. organs were stronger than in the case of Nuphar lutea and were as follows: $\mathrm{Ni}$ root - stem (0.48), stem - leaf (0.62), Pb root - stem (0.76), stem leaf (0.44), Cd stem - leaf (0.63).
Results of the Cd content for bottom sediments and Typha latifolia L. were very similar to the previous CA results (Nuphar lutea) (Fig. 9). The second group is also the $\mathrm{Cd}$ content in the bottom sediments, roots, stems and leaves. The CA results indicate the variability of $\mathrm{Cd}$ content, which were similarly shaped as in the case of sediments and Nuphar lutea, which refers to the previous observations. At the same time, analyses confirm the conclusions related to the exceeding geochemical background in the bottom sediments and high values of bioaccumulation coefficients in the case of Cd.

Based on the FA analysis, two factors were identified, the first of which explains $30 \%$ of cumulative variability and the other 19\% (Tab. 7). The first factor is related to the bioaccumulation of $\mathrm{Pb}$ by all Typha latifolia L. organs, which may be related to transport emissions in the study areas. The second factor explains the accumulation of $\mathrm{Cd}, \mathrm{Ni}$ and $\mathrm{Pb}$ by the bottom sediments, but the intensity of this factor is much lower. Therefore, it can be presumed that the $\mathrm{Pb}$ biosorption is more intense for Typha latifolia L., but not from the bottom sediments, but only taking the dissolved $\mathrm{Pb}$ forms from the river water. The FA results did not confirm the CA results.

\section{Table 7}

The factor loadings after the varimax rotation of the sediments and macrophytes data. Values indicate statistically significant scores $\geq 0.70$

\begin{tabular}{|l|c|c|}
\hline \multicolumn{1}{|c|}{ Parameters } & Factor $\mathbf{1}$ & Factor 2 \\
\hline Root $\mathrm{Ni}$ & 0.57 & -0.16 \\
\hline Stem $\mathrm{Ni}$ & 0.61 & 0.37 \\
\hline Leaf $\mathrm{Ni}$ & 0.59 & -0.15 \\
\hline Root $\mathrm{Pb}$ & 0.89 & 0.14 \\
\hline $\mathrm{Stem} \mathrm{Pb}$ & 0.84 & 0.27 \\
\hline Leaf $\mathrm{Pb}$ & 0.87 & -0.04 \\
\hline Root $\mathrm{Cd}$ & -0.18 & -0.50 \\
\hline Stem $\mathrm{Cd}$ & -0.44 & 0.09 \\
\hline Leaf Cd & -0.61 & 0.36 \\
\hline Acidity $(\mathrm{pH})$ & -0.21 & 0.57 \\
\hline MO & -0.49 & 0.26 \\
\hline Ni sediment & 0.01 & 0.82 \\
\hline Pb sediment & -0.18 & 0.70 \\
\hline Cd sediment & -0.09 & 0.72 \\
\hline \% Variance & 30 & 19 \\
\hline
\end{tabular}






Fig. 9. Dendrogram of hierarchical cluster analysis (Ward's method) sediment - Typha latifolia L

\section{CONCLUSIONS}

1. The obtained results of bottom sediments and plant material analyses indicate the lack of pollution of the aquatic environment of the Ełk River and its tributaries by nickel and lead. In contrast, the cadmium content is somewhat raised.

2. The obtained test results showed a higher content of nickel and lead in the bottom sediments than in the plants; cadmium displayed similar mean values both in plants and sediments. The studied macrophytes Nuphar lutea and Typha latifolia L. showed a different ability to accumulate nickel, lead and cadmium in plant organs. The smallest share of nickel and lead was recorded in stems, with cadmium in the leaves. The aquatic plants can be bioindicators of metal contamination of the Ełk River and its tributaries.

3. Statistical CA analysis of the metal concentrations in the bottom sediments; Nuphar lutea and Typha latifolia L. showed two groups characterized by differing contents of metals. One of these groups is associated only with $\mathrm{Cd}$, which confirmed the thesis concerning its slightly larger quantities in the examined environment in relation to other metals.
4. The FA factor analyses indicated, among others, the processes of mobilizing elements from the bottom sediments as a result of decreasing reaction and their simultaneous absorption by macrophyte roots and sorption processes of metal ions by macrophytes from river waters and their less intensive accumulation in the bottom sediments.

5. It has been proven that the environmental quality of the Ełk River and its tributaries, shaped by natural factors, is lowered by the multidirectional economic and living activity of man.

The research was carried out as a part of the work No. S/WBiIŚ/3/2014 and financed from the resources for education by The Ministry of Science and Higher Education.

\section{REFERENCES}

Ali I. \& Jain C.K., 2001. Pollution potential of toxic metals in the Yamuna river at Delhi, India. Journal of Environmental Hydrology, 12, 9, 1-9.

Baldantoni D., Maisto G., Bartoli G. \& Alfami A., 2005. Analyses of three native aquatic plant species to assess spatial gradients of lake trace element contamination. Aquatic Botany, 83, 48-60. 
Baldantoni D., Alfani A., Di Tommasi P., Bartoli G. \& De Santo A., 2004. Assessment of macro and microelement accumulation capability of two aquatic plants. Environmental Pollution, 130, 149-156.

Bielski A., 2012. Wpływ zrzutu nieoczyszczonych ścieków na środowisko wodne cieku. Inżynieria i Ochrona Środowiska, 15(2), 119-142.

Bojakowska I., 2001. Kryteria oceny zanieczyszczenia osadów wodnych. Przeglad Geologiczny, 49(3), 213-218.

Bonanno G. \& Lo Giudice R., 2010. Heavy metal bioaccumulation by the organs of Phragmites Australis (common reed) and their potential use as contamination indicators. Ecological Indicators, 10, 639-645.

Bonanno G. \& Vymazal J., 2017. Compartmentalization of potentially hazardous elements in macrophytes: Insights into capacity and efficiency of accumulation. Journal of Geochemical Exploration, 181, 22-30.

Bragato C., Brix H. \& Malagoli M., 2006. Accumulation of nutrients and heavy metals in Phragmites australis (cav.) trin. ex steudel and Bolboschoenus maritimus (l.) palla in a constructed wetland of thevenice lagoon watershed. Environmental Pollution, 144, 967-975.

Cardwell A.J., Hawker D.W. \& Greenway M., 2002. Metal accumulation in aquatic macrophytes from southeast Queensland, Australia. Chemosphere, 48, 653-663.

Choiński A., Ditta J.B. \& Ławniczak A.E., 2010. Ocena stanu zanieczyszczenia $\mathrm{Cu}, \mathrm{Zn}, \mathrm{Pb}$ i Cd osadów dennych Jeziora Niepruszewskiego. [in:] Ciupa T. \& Suligowski R. (red.), Woda w badaniach geograficznych, Instytut Geografii Uniwersytetu Humanistyczno-Przyrodniczego Jana Kochanowskiego, Kielce, 159-167.

Dąbrowska J. \& Lejcuś K., 2012. Charakterystyka osadów dennych zbiornika Dobromierz. Infrastruktura i Ekologia Terenów Wiejskich, 3(IV/2), 89-98.

Demirak A., Yilmaz F., Levent Tuna A. \& Ozdemir N., 2006. Heavy metals in water, sediment and tissues of Leuciscus cephalus from a stream in southwestern Turkey. Chemosphere, 63, 1451-1458.

Deng H., Ye Z.H. \& Wong M.H., 2004. Accumulation of lead, zinc, copper and cadmium by 12 wetland plant species thriving in metal-contaminated sites in China. Environmental Pollution, 132, 29-40.

Dong D.M., Li H.L., Li Y., Fang C.S., Li X.H. \& Xu C.Y., 2004. Distribution of heavy metals in the sediments from the Yitong River: Changchun Section. Research of Soil and Water Conservation, 11(1), 95-96, 136.

Fediuc E. \& Erdei L., 2002. Physiological and biochemical aspects of cadmium toxicity and protective mechanisms induced in Phragmites australis and Typha latifolia. Journal of Plant Physiology, 159, 265-271.

Fritioff A. \& Greger M., 2006. Uptake and distribution of Zn, $\mathrm{Cu}, \mathrm{Cd}$, and $\mathrm{Pb}$ in an aquatic plant Potamogeton natans. Chemosphere, 63, 220-227.

Głosińska G. \& Siepak J., 2007. Zanieczyszczenie środkowej i dolnej Odry wybranymi metalami ciężkimi w latach 1991-2005 na podstawie wyników monitoringu geochemicznego osadów dennych. Rocznik Ochrona Środowiska, 9, 167-182.

Gundersen P. \& Steinnes E., 2001. Influence of temporal variations in river discharge, $\mathrm{pH}$, alkality and $\mathrm{Ca}$ on the speciation and concentration of heavy metals in some mining polluted rivers. Aquatic Geochemistry, 7, 173-193.
Häkanson L., 1980. An ecological risk index for aquatic pollution control - a sedimentological approach. Water Research, 14, 975-1101.

Hanif N., Shah Eqani S., Ali S.M., Cincinelli A., Ali N., Katsoyiannis I.A., Tanveer Z.I. \& Bokhari H., 2016. Geo-accumulation and enrichment of trace metals in sediments and their associated risks in the Chenab River, Pakistan. Journal of Geochemical Exploration, 165, 62-70.

Harada E., Hhoi Y.E., Tsuchisaka A., Obata H. \& Sano H., 2001. Transgenic tobacco plants expressing a rice cysteine synthase gene are tolerant to toxic levels of cadmium. Journal of Plant Physiology, 158(5), 655-661.

Harguinteguy C.A., Cirelli A.F. \& Pignata L.M., 2014. Heavy metal accumulation in leaves of aquatic plant Stuckenia filiformis and its relationship with sediment and water in the Suquía river (Argentina). Microchemical Journal, $114,111-118$.

Hejabi A.T. \& Basavarajappa H.T., 2013. Heavy metals partitioning in sediments of the Kabini River in South India. Environmental Monitoring and Assessment, 185, 1273-1283.

Huang K.M. \& Lin S., 2003, Consequences and implication of heavy metal spatial variations in sediments of the Keelung River drainage basin, Taiwan. Chemosphere, 53, 1113-112

Ibragimow A., Głosińska G., Siepak M. \& Walna B., 2010. Heavy metals in sediments of the Odra river flood-plains-introductory research. Geography Quest, 29/1, 37-47.

Kabata-Pendias A. \& Pendias H., 1999. Biogeochemia pierwiastków śladowych. Wydawnictwo Naukowe PWN, Warszawa.

Klavins M., Briede A., Rodinov V., Kokorite I., Parele E. \& Klavina I., 2000. Heavy metals in rivers of Latvia. Science of the Total Environment, 262, 1-2, 175-183.

Królak E., Korycińska M., Diadik K. \& Godziuk S., 2011. Czy lokalne oczyszczalnie ścieków wpływają na jakość wód w ich odbiornikach. Ochrona Środowiska i Zasobów $\mathrm{Na}$ turalnych, 48, 343-352.

Lis J. \& Pasieczna A., 1995. Atlas geochemiczny Polski 1:2 500 000. Państwowy Instytut Geologiczny, Warszawa.

Mazej Z. \& Germ M., 2009. Trace element accumulation and distribution in four aquatic macrophytes. Chemosphere, 74, 642-647.

Melville F. \& Pulkownik A., 2007. Investigation of mangrove macroalgae as biomonitors of estuarine metal contamination. Science of the Total Environment, 387, 1-3, 301-309.

Morales-García S.S., Rodríguez-Espinosa P.F., Shruti V.C., Jonathan M.P. \& Martínez-Tavera E., 2017. Metal concentrations in aquatic environments of Puebla River basin, Mexico: natural and industrial influences. Environmental Science and Pollution Research, 24, 2589-2604.

Müller G., 1979. Schwermetalle in den sedimenten des Rheins-Veranderungen seitt. Umschau, 79, 778-783.

Olivares-Rieumont S., De La Rosa D., Lima L., Graham D.W., D'Alessandro K., Borroto J. et al., 2005. Assessment of heavy metal levels in Almendares river sediments - Havana City, Cuba. Water Research, 39, 16, 3945-3953.

Rabajczyk A. \& Jóźwiak M.A., 2008. Możliwości wykorzystania makrofitów jako bioindykatorów metali ciężkich zdeponowanych w osadach dennych. Monitoring Środowiska Przyrodniczego, 9, 19-26. 
Rainbow P.S. \& Phillips D.J.H., 1993. cosmopolitan biomonitors of trace metals. Marine Pollution Bulletin, 26, 11, 593-601.

Samecka-Cymerman A. \& Kempers A.J., 2004. Toxic metals in aquatic plants surviving in surface water polluted by copper mining industry. Ecotoxicology and Environmental Safety, 59, 64-69.

Shen Z.J., Xua D.C., Chena Y.S. \& Zhang Z., 2017. Heavy metals translocation and accumulation from the rhizosphere soils to the edible parts of the medicinal plant Fengdan (Paeonia ostii) grown on a metal mining area, China. Ecotoxicology and Environmental Safety, 143, 19-27.

Shrestha S. \& Kazama F., 2007. assessment of surface water quality using multivariate statistical techniques: a case study of the fuji river basin, japan. Environmental Modelling \& Software, 22, 4, 464-475.

Singh K.P., Malik A., Sinha S., Singh V.K. \& Murthy R., 2005. Estimation of source of heavy metal contamination in sediments of Gomti river (India) using principal component analysis. Water, Air, \& Soil Pollution, 166, 321-341.

Skorbiłowicz E., 2014. Assessment of heavy metals contents in bottom sediments of Bug river. Journal of Ecological Engineering, 15, 3, 82-89.

Skorbiłowicz E., Skorbiłowicz M. \& Malinowska D., 2016. Accumulation of heavy metals in organs of aqueous plants and its association with bottom sediments in Bug river (Poland). Journal of Ecological Engineering, 17, 4, 295-303.

Sojka M., Siepak M. \& Gnojska E., 2013. Ocena zawartości metali ciężkich w osadach dennych wstępnej części zbiornika retencyjnego Stare Miasto na rzece Powie. Ochrona Środowiska, 15, 1916-1928.

Stoltz E. \& Greger M., 2002. Accumulation properties of as, $\mathrm{Cd}, \mathrm{Cu}, \mathrm{Pb}$ and $\mathrm{Zn}$ by four wetland plant species growing on submerged mine tailings. Environmental and Experimental Botany, 47, 271-280.
Swennen R. \& Van der Sluys J., 2002. Anthropogenic impact on sediment compositionand geochemistry in vertical overbank profiles of river alluvium from Belgium and Luxembourg. Journal of Geochemical Exploration, 75, 93-105.

Szarek-Gwiazda E., 2013. Czynniki kształtujące stężenia metali ciężkich $w$ rzece rabie i niektórych karpackich zbiornikach zaporowych. Instytut Ochrony Przyrody PAN, Kraków.

Szydłowski K. \& Podlasińska J., 2016. Stężenia wybranych metali ciężkich w osadach dennych cieku wodnego. Infrastruktura i Ekologia Terenów Wiejskich, I/1, 2016, 59-71.

Turekian K.K. \& Wedepohl K.H., 1961. Distribution of the elements in some major units of the earth's crust. Geological Society of America Bulletin, 72, 175-182.

Weis J.S. \& Weis P., 2004. Metal uptake, transport and release by wetland plants: implications for phytoremediation and restoration. Environment International, 30, 685-700.

Wojtkowska M., 2014. Heavy metals in water, sediments and plants of the Zegrzyński Lake. Progress in Plant Protection, 54, 1, 95-101.

Xiaolei Z., Baoqing S., Wenzhong T., Shanshan L. \& Nan R., 2016. Distributions, fluxes and toxicities of heavy metals in sediment pore water from tributaries of the Ziya River system, northern China. Environmental Science and Pollution Research, 23, 6, 5516-5526.

Zhao Y., Marriott S., Rogers J. \& Iwugo K.,1999. A preliminary study of heavy metal distribution on the floodplain of the River Severn, UK by a single flood vent. Science of the Total Environment, 243/244, 219-231.

Zurayk R., Sukkariah B. \& Baalbaki R., 2001. Common hydrophytes as bioindicators of nickel, chromium and cadmium pollution. Water, Air and Soil Pollution, 127, 373-388. 